\title{
Moderate Intensity Physical Exercise Decreases Gastrocnemius Caspase-3 Expression on Mus musculus with Statin Treatment
}

\section{Junita Jeanne Paliman ${ }^{1}$, Ratna Darjanti Haryadi ${ }^{1}$, Rwahita Satyawati Darmanta ${ }^{1}$, Willy Sandhika ${ }^{2}$, Martha Kurnia Kusumawardani ${ }^{1}$}

1 Department of Physical Medicine and Rehabilitation, Faculty of Medicine, Universitas Airlangga, Dr Soetomo General Hospital, Surabaya, Indonesia

2 Department of Anatomical Pathology, Faculty of Medicine, Universitas Airlangga, Dr Soetomo General Hospital, Surabaya, Indonesia

\begin{abstract}
Introduction: Dyslipidemia is a lipid metabolism abnormality marked by increase or decrease of lipid fraction in the plasma. Statin or 3-Hydroxy-3-Methylglutaryl coenzyme A (HMG-CoA) reductase inhibitor is an important dyslipidemia medication that may induce apoptosis of the skeletal muscle. Decrease of Bcl-2 and Bax ratio causing caspase- 9 activation followed by caspase-3 activation occur in apoptosis. Moderate intensity physical exercise (MIPE) decreases DNA fragmentation, increases Bcl-2 protein level and decreases Bax transcript level.

Methods: Thirty healthy BALB/C strain Mus musculus divided into 3 groups: first intervention group with statin only treatment $(\mathrm{S})$, second intervention group with statin treatment plus MIPE using motorized treadmill (ST), and control (C) group with no statin and nor exercise. The duration of treatment was 28 days. Statin treatment dose was $2.06 \mathrm{mg} / \mathrm{kg}$ bodyweight. Measurement caspase-3 was done by immunohistochemistry evaluation and the expression of capase-3 was calculated by cells count which expressing caspase-3.
\end{abstract}

Results: There were more muscle cells expressing caspase- 3 in the S group $(47.00 \pm 12.92$ cells $)$ than the C group $(2.70 \pm 1.94$ cells $) ; p=0.000$, the ST group $(21.44 \pm 10.13$ cells $)$ than the $\mathrm{C}$ group $(\mathrm{p}=0.001)$, as well as $\mathrm{S}$ group and the ST group $(\mathrm{p}=0.000)$.

Conclusion: Moderate intensity physical exercise can decrease caspase-3 expression in statin treated subject.

Keywords: apoptosis, caspase-3, dyslipidemia, moderate intensity physical exercise, statin. 


\begin{abstract}
ABSTRAK
Pendahuluan: Dislipidemia merupakan kelainan metabolisme lipid yang ditandai dengan peningkatan atau penurunan fraksi lipid dalam plasma. Statin atau 3-Hydroxy-3-Methylglutaryl coenzyme A (HMGCoA) reductase inhibitor adalah obat dislipidemia penting yang dapat menginduksi apoptosis otot rangka. Penurunan rasio Bcl-2 dan Bax menyebabkan aktivasi caspase-9 diikuti oleh aktivasi caspase-3 pada apoptosis. Latihan fisik intensitas sedang (MIPE) menurunkan fragmentasi DNA, meningkatkan kadar protein Bcl-2 dan menurunkan kadar transkrip Bax.
\end{abstract}

Metode: Tiga puluh BALB/C sehat strain Mus musculus dibagi menjadi 3 kelompok: kelompok intervensi pertama dengan pengobatan statin saja (S), kelompok intervensi kedua dengan pengobatan statin ditambah MIPE menggunakan treadmill bermotor (ST), dan kelompok kontrol (C) dengan tidak ada statin dan atau olahraga. Durasi pengobatan adalah 28 hari. Dosis pengobatan statin adalah 2,06mg/ kg BB. Pengukuran caspase-3 dilakukan dengan evaluasi imunohistokimia dan ekspresi capase-3 dihitung dengan jumlah sel yang mengekspresikan caspase-3.

Hasil: Sel otot yang mengekspresikan caspase-3 lebih banyak pada kelompok S (47,00 $\pm 12,92 \mathrm{sel})$ daripada kelompok C $(2,70 \pm 1,94 \mathrm{sel}) ; \mathrm{p}=0,000$, kelompok ST $(21,44 \pm 10,13 \mathrm{sel})$ dibandingkan kelompok $\mathrm{C}(\mathrm{p}=0,001)$, serta kelompok S dan kelompok ST $(\mathrm{p}=0,000)$.

Kesimpulan: Latihan fisik intensitas sedang dapat menurunkan ekspresi caspase-3 pada subjek yang mendapat terapi statin.

Kata Kunci: apoptosis, caspase-3, dislipidemia, latihan fisik intensitas sedang, statin.

Correspondent Details:

\section{Martha Kurnia Kusumawardani}

Email: marthakurnia@staf.unair.ac.id

Department of Physical Medicine and

Rehabilitation, Faculty of Medicine,

Universitas Airlangga

DR. Soetomo General Hospital,

Surabaya, Indonesia

\section{INTRODUCTION}

Dyslipidemia is a lipid metabolism abnormality marked by increase or decrease of lipid fraction in the plasma. Indonesia National Basic Health Research in 2018 showed that $31 \%$ of persons age $\geq 15$ years had abnormal cholesterol levels according to National Cholesterol Education Program Adult Treatment Panel III, with a cholesterol level $\geq 200 \mathrm{mg} / \mathrm{dl}{ }^{1}$

Statin or 3 - Hydroxy - 3 - Methylglutaryl coenzyme A (HMG-CoA) reductase inhibitor is an important dyslipidemia medication working as an inhibitor of HMG-CoA enzym controlling intracellular and intrahepatal cholesterol regulation and production. ${ }^{2}$ Statin may induce apoptosis of the skeletal muscle myoblast by mitochondria mediated decrease of Bcl-2 and Bax ratio which will cause release of cytochrome-c and activation of caspase-9, followed by activation of caspase- $3 .^{3}$ 
Aerobic training using treadmill and strength training for 12 weeks, $3 \mathrm{x} /$ week in statin users can lower lipid profile and LDL levels4. Moderate intensity physical exercise (MIPE) can decrease DNA fragmentation, increase Bcl-2 protein, and decrease Bax transcript level. ${ }^{5}$ The effect of physical exercise on apoptosis regulation is still not well understood. In a study on the correlation between acute physical exercise and skeletal muscle apoptosis, Reactive Oxygen Species (ROS) was known as a stimulus that may activate the apoptosis. ${ }^{6}$

The aim of this study is to compare the amount of muscle cells expressing caspase-3 expression in BALB/C strain Mus musculus.

\section{METHODS}

\section{Study design}

This was an experimental study, with post test only control group design. Subjects were 30 healthy male BALB/C strain Mus musculus 12-weeks old, weighing around 20-25 grams. Ethical clearance was obtained from the Airlangga University Medical Faculty Ethical Commision for basic and clinical research.

\section{Study Protocol}

After 7 days of acclimatization, 30 subjects were randomized into 3 groups. statin only treatment group $(\mathrm{S})$, statin treatment plus exercise (ST) and a control (C) group without statin nor exercise. Weight measurements were done on the $1^{\text {st }}, 14^{\text {th }}, 28^{\text {th }}$ day. Statin treatment for the S and ST groups was per oral galvage of atorvastatin $2.06 \mathrm{mg} / \mathrm{kg}$ bodyweight by Fr8 pediatric nasogastric tube daily for 28 days. The ST group MIPE was running on a motorized treadmill using the Southern et al. protocol $^{7} 30$ minutes per session, $3 \mathrm{x} /$ week. The first 7 minutes was done on $7.5 \mathrm{~m} / \mathrm{min}$ speed, increased to $10 \mathrm{~m} / \mathrm{min}$ for the next 7 minutes, and then increased to $12.5 \mathrm{~m} / \mathrm{min}$ for the last 16 minutes, all on $5 \%$ inclination. Treatment for the $\mathrm{C}$ group was aqua destilata 1-2 $\mathrm{ml}$ weight adjusted by a Fr8 pediatric nasogastric tube daily for 28 days. Subjects were terminated on the $29^{\text {th }}$ day of the study under anesthesia. The right gastrocnemius muscle was extracted for histopathology examination and fixed using normal formalin buffer liquid, sliced cross sectionally, stained with caspase-3 immunohistochemistry dye and counted under a light microscope with 100x magnification.

\section{Statistic analysis}

Data analysis was done using SPSS 22.0. The total number of caspase-3 expressing muscle cells percentage data of the groups were tested using Shapiro-Wilk tests of normality, if the data was normally distributed, followed by ANOVA test (Analysis of Variance), significant when $(p<0.05)$, or followed by Kruskal wallis test if the distribution of the data was not normal.

\section{RESULT}

Thirty subjects enrolled, 29 subjects finished the study. One subject died during the study. Characteristics of the subjects are shown in Table 1. 
Table 1. Age and weight of subjects before statin treatment

\begin{tabular}{ccccc}
\hline Group & N & Age & Weight & p \\
\hline S & $\mathbf{1 0}$ & 12 & $22.50 \pm 1.71$ & \\
ST & 10 & 12 & $22.90 \pm 1.59$ & 0.762 \\
C & 10 & 12 & $23.00 \pm 2.00$ & \\
\hline
\end{tabular}

Note: age (weeks), weight (grams). Level of significance (alfa) was set to 0.05

wThe body weight of the subjects in the C group and ST group was homogenous while $\mathrm{S}$ group was not. Kruskal-Wallis test showed no significant difference of the weight between the three groups before treatment $(p=0.762)$. Immunochemistry slides can be seen at Figures 1, 2 and 3.

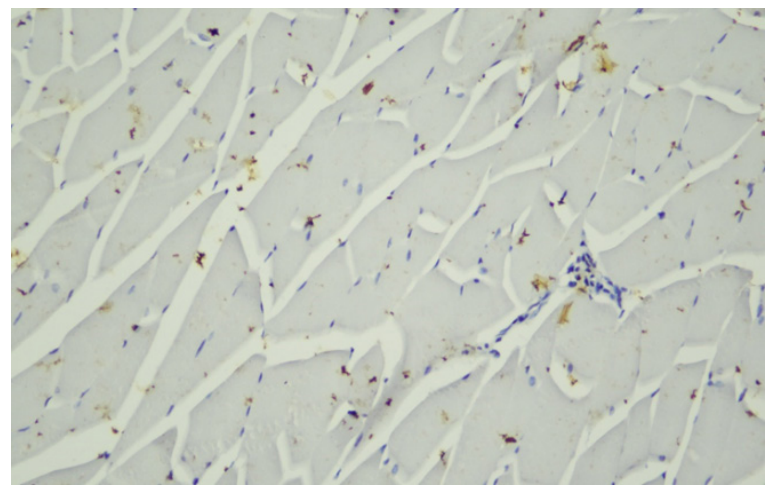

Figure 1. Immunohistochemistry cross sectional section of the $\mathbf{C}$ group gastrocnemius muscle (100x magnification)

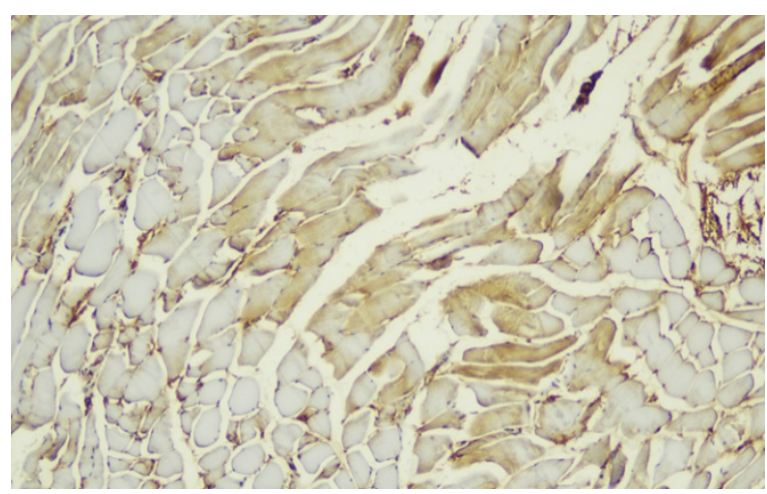

Figure 2.Immunohistochemistry cross sectional section of the $S$ group gastrocnemius muscle (100x magnification)

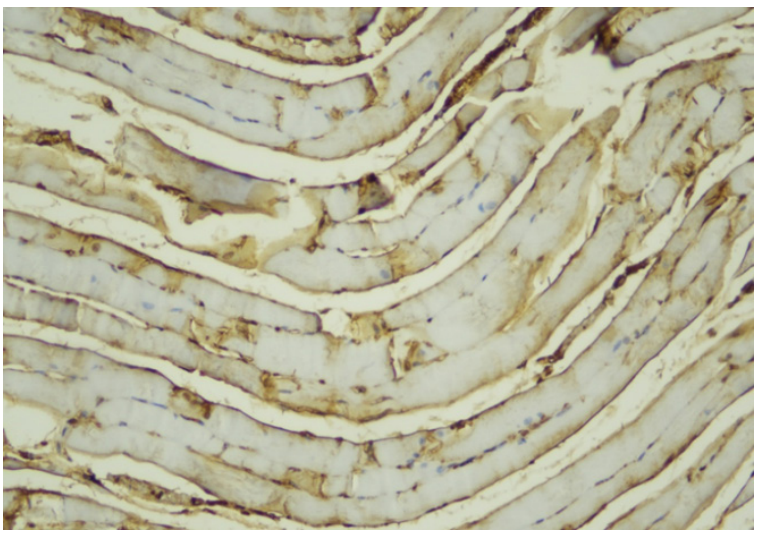

Figure 3. Immunohistochemistry cross sectional section of the $\mathrm{ST}$ group gastrocnemius muscle (100x magnification)

Arrows are pointing at caspase-3 expressing cells. Results of caspase- 3 expressing muscle cell count is at Table 2.

Table 2. Average of muscle cells percentage of caspase- 3 expressing gastrocnemius muscle cells.

\begin{tabular}{ccc}
\hline Group & N & Mean \pm SD (\%) \\
\hline S & 10 & $47.00 \pm 12.92$ \\
ST & 9 & $21.44 \pm 10.13$ \\
C & 10 & $2.70 \pm 1.94$ \\
\hline
\end{tabular}

Saphiro-Wilk test showed normal distribution of the data. ANOVA test showed significant difference $(p<0.05)$ in the percentage number of caspase- 3 expressing gastrocnemius muscle cells between three groups (Table 3 ) followed by multiple comparisons to investigate differences between each group is shown in Table 4. 
Table 3. ANOVA test of the number of caspase-3 expressing gastrocnemius muscle cells

\begin{tabular}{cccccc}
\hline & Sum of squares & df & Mean Square & F & p \\
\hline Between group & 9884.436 & 2 & 4942.218 & & \\
Within group & 2360.322 & 26 & 90.782 & 54.441 & 0.00 \\
Total & 12244.759 & 28 & & & \\
\hline
\end{tabular}

Level of significance (alfa) was set to 0.05

Tabel 4. Multiple Comparisons test of the number of caspase-3 expressing gastrocnemius muscle cells

\begin{tabular}{ccccc}
\hline Group $(\mathbf{I})$ & Group $(\mathbf{J})$ & Mean Difference $(\mathbf{I}-\mathbf{J})$ & Std.Error & $\mathbf{p}$ \\
\hline \multirow{2}{*}{ Control } & Statin & $-44.30000^{*}$ & 4.13401 & $0.000^{*}$ \\
& Statin + Treadmill & $-18.74444^{*}$ & 3.43492 & $0.001^{*}$ \\
\multirow{2}{*}{ Statin } & Control & $44.30000^{*}$ & 4.13401 & $0.000^{*}$ \\
& Statin+ Treadmill & $25.55556^{*}$ & 5.30385 & $0.000^{*}$ \\
\multirow{3}{*}{ Statin + Treadmill } & Control & $18.74444^{*}$ & 3.43492 & $0.001^{*}$ \\
& Statin & $25.55556^{*}$ & 5.30385 & $0.000^{*}$ \\
\hline
\end{tabular}

Level of significance (alfa) was set to $0,05(5 \%)$.

Significant differences found in the number of caspase-3 expressing gastrocnemius muscle cells between the $\mathrm{C}$ group and $\mathrm{S}$ group $(\mathrm{p}=0.000)$, as well as between the $\mathrm{C}$ group and $\mathrm{ST}$ group $(\mathrm{p}=0.001), \mathrm{S}$ group and $\mathrm{ST}(\mathrm{p}=0.000)$. There were muscle cells expressing caspase- 3 in the $\mathrm{S}$ group (47.00 \pm 12.92 cells), the $C$ group ( $2.70 \pm 1.94$ cells), the ST group (21.44 \pm 10.13 cells $)$.

\section{DISCUSSION}

This study showed that caspase-3 expressing muscle cells percentage was significantly increased, (94.2\%) higher in the $\mathrm{S}$ group compared with the $\mathrm{C}$ group $(\mathrm{p}=0.000)$. This goes in hand with the study by Ahmed et al. in 3 groups of mice given atorvastatin $10 \mathrm{mg} /$ $\mathrm{kg}, 40 \mathrm{mg} / \mathrm{kg}$ and $80 \mathrm{mg} / \mathrm{kg}$ body weight respectively for 8 weeks, showing increased caspase-3 expression in the medial vastus muscles when compared with a no statin control group. Caspase-3 plays a role in apoptosis, therefore the number of muscle cells showing caspase-3 expression may be considered as an indicator evaluated in immunohistochemistry examination. ${ }^{8}$ Sacher et al. ${ }^{9}$ reported elevation of cytosol calcium level as a response of calpain activation which may induce apoptosis through Bax translocation to mitochondria and activate caspase- 9 and caspase-3, due to statin use. A study by Bouitbir et al. ${ }^{10}$ has shown that atorvastatin $10 \mathrm{mg} / \mathrm{kg}$ bodyweight can reduce mitochondrial biogenesis and markedly decrease PGC-1 $\alpha$ mRNA expression, and elevate mRNA ROS production.

The ST group of this study showed a significantly $(\mathrm{p}=0.001)$ higher percentage, i.e. $87.40 \%$ of caspase-3 expressing muscle cell 
average when compared with $\mathrm{C}$ group. This number is lower than in the $\mathrm{S}$ only group, demonstrating the physical exercise protective effect towards statin adverse effect. Siu et al. ${ }^{5}$ showed that MIPE increased HSP70, Bcl2, MnSOD protein levels in animal subjects and therefore have an anti apoptosis role. A high HSP70 level will supress the caspase-3 level, decreasing DNA fragmentation. Southern et al. ${ }^{7}$ stated that animal subjects treated with statin and treadmill exercise showed an increase of PGC-1 $\alpha$ compared to the statin group. Endurance exercise can stimulate mitochondria biogenesis and increase aerobic capacity by way of PGC- $1 \alpha$ transcription. Chung et al stated that mitochondrial expansion neutralize excessive oxidative stress. PGC- $1 \alpha$ may supress FoxO3 actvity and FoxO target gene expression, decreasing atrogin I gene expression level ensuring good protein synthesis and no mitochondrial dysfunction. This supports the potential of endurance exercise in prevention of statin induced myopathy. ${ }^{11}$

This study result showed a significantly $(p=0.000) 54.3 \%$ higher average number of caspase-3 expressing gastrocnemius muscle cells in the $\mathrm{S}$ group compared to the ST group. Bouitbir et al. ${ }^{9}$ has shown the protective side of MIPE for mitochondria from atorvastatin adverse effect. Mitochondrial respiration (Vmax) was $29.8 \%$ better with $120 \%$ increase of $\mathrm{H} 2 \mathrm{O} 2$ in the atorvastatin and physical exercise group compared to the statin only group. MIPE exercise activates PGC- $1 \alpha$ which controls the mitochondrial biogenesis so that the contractile muscle proteins bulding process can happen and prevent cell damage caused by statin use.
Limitations in this study are the relatively short study duration of 28 days that may only cause microscopic changes, and that this study only used caspase-3 as a marker of apoptosis while nucleus fragmentation as physical evidence of apoptosis was not observed.

\section{CONCLUSION}

From the results of this study we can conclude that the amount of muscle cells expressing caspase-3 of BALB/C strain Mus musculus was highest in the statin only group. In the statin plus moderate intensity physical exercise group the amount of muscle cells expressing caspase-3 of BALB/C strain Mus musculus was lower than in the statin only group. Both treatments groups had a higher amount of muscle cells expressing caspase-3 than the no treatment group. Therefore this study has shown that moderate intensity physical exercise can decrease caspase-3 expression in statin treated subjects and Statin the most important anti dylipidemia.

\section{REFERENCES}

1. Indonesia PE. Pengelolaan dan Pencegahan Dislipidemia di Indonesia. PB. PERKENI. 2015.

2. Accioly MF, Camargo Filho JC, Padulla SA, Lima AL, Bonfim MR, Carmo EM, et al. Effect of physical exercise and statins on the muscle function in animals with dyslipidemia. Rev. Bras. de Medicina do Esporte 2012; 18(3): 198-202.

3. Dirks AJ, Jones KM. Statin-induced apoptosis and skeletal myopathy. Am J Physiol Cell 
Physiol 2006; 291(6): C1208-12.

4. Bonfim MR, Oliveira AS, Amaral SL, Monteiro HL. Treatment of dyslipidemia with statins and physical exercises: recent findings of skeletal muscle responses. Arq Bras Cardiol 2015; 104(4): 324-31.

5. Siu PM, Bryner RW, Martyn JK, Alway SE. Apoptotic adaptations from exercise training in skeletal and cardiac muscles. The FASEB journal 2004; 18(10): 1150-2.

6. Schelman WR, Andres RD, Sipe KJ, Kang E, Weyhenmeyer JA. Glutamate mediates cell death and increases the Bax to Bcl-2 ratio in a differentiated neuronal cell line. Brain Res Mol 2004; 128(2): 160-9.

7. Southern WM, Nichenko AS, Shill DD, Spencer CC, Jenkins NT, McCully KK, et al. Skeletal muscle metabolic adaptations to endurance exercise training are attainable in mice with simvastatin treatment. PloS one 2017 ; 12(2): e 0172551.
8. Ahmed S, Saber EA, Hamouda AH, Rifaai RA. Structural Changes in the Skeletal Muscle Fiber of Adult Male Albino Rat Following Atorvastatin Treatment; the Possible Mechanisms of Atorvastatin Induced Myotoxicity. J Cytol Histol 2017; 8: 442.

9. Sacher J, Weigl L, Werner M, Szegedi C, Hohenegger M. Delineation of myotoxicity induced by 3-hydroxy-3-methylglutaryl CoA reductase inhibitors in human skeletal muscle cells. J Pharmacol Exp Ther 2005; 314(3): 1032-41.

10. Bouitbir J, Daussin F, Charles AL, Rasseneur L, Dufour S, Richard R, et al. Mitochondria of trained skeletal muscle are protected from deleterious effects of statins. Muscle Nerve 2012; 46(3): 367-73.

11. Chung HR, Vakil M, Munroe M, Parikh A, Meador BM, Wu PT, et al. The impact of exercise on statin-associated skeletal muscle myopathy. PloS one 2016; 11(12): p.e0168065. 